\title{
TRANSISI KEMAMPUAN BERPIKIR ARITMATIKA KE KEMAMPUAN BERPIKIR ALJABAR PADA PEMBELAJARAN MATEMATIKA
}

\author{
Weni Dwi Pratiwi ${ }^{1}$, Elika Kurniadi ${ }^{2}$ \\ 1wenidwipratiwi@gmail.com, 2 elikakurniadi@gmail.com \\ ${ }^{1,2}$ Universitas Sriwijaya \\ 2018
}

\begin{abstract}
Abstrak
Studi terdahulu menunjukkan bahwa peran aljabar pada pembelajaran saat ini terfokus pada banyak perspektif sehingga pembelajaran aljabar tradisional membutuhkan pembaharuan yang fundamental dan juga perubahan cara berpikir. Pembelajaran aljabar saat ini harus dapat difokuskan kepada penguasaan dan pengaplikasian aljabar di berbagai konteks dalam kehidupan sehari-hari. Studi dilakukan dengan tujuan untuk mendapatkan gambaran tentang adanya transisi kemampuan berpikir dari aritmatika ke aljabar. Jenis penelitian ini adalah deskriptif kualitatif. Hasil penelitian menunjukkan bahwa indikator transisi kemampuan berpikir aritmatika ke kemampuan berpikir aljabar sudah dapat tercapai dengan baik, hanya saja siswa masih melakukan kekeliruan pada saat mengerjakan operasi bilangan negatif karena siswa sulit membedakan antara tanda bilangan dan juga tanda operasi yang terlibat dalam operasi tersebut. Hal ini harusnya dapat diantisipasi mengingat hal tersebut sangat diperlukan dalam pemahaman aljabar tingkat lanjut
\end{abstract}

Kata kunci: kemampuan berpikir aritmatika, kemampuan berpikir aljabar

\begin{abstract}
Existing study revealed that the role of algebra in today's learning is focused on many perspectives so that traditional algebra learning requires fundamental renewal as well as change of way of thinking. Algebra learning today should be focused more on mastering and applying algebra in various contexts of everyday life. The study was conducted with the aim to get a picture of the transition of thinking ability from arithmetic to algebra. The type of this research is descriptive qualitative. The results showed that the transition indicator of the ability of arithmetic thinking to the ability of algebraic thinking can be achieved well, only the students still make mistakes when performing negative number operations because students face difficulty in distinguishing the number sign and the sign of operation involved in the operation. This should be anticipated considering it indispensable in advanced algebra.
\end{abstract}

Keywords: arithmetic thinking ability, algebraic thinking ability 


\section{JURNAL GANTANG. Maret 2018; III(1): 1 - 8 \\ p-ISSN. 2503-0671 \\ e-ISSN. 2548-5547}

\section{Pendahuluan}

Aljabar formal pada pembelajaran sekolah saat ini terfokus pada banyak perspektif sehingga pembelajaran aljabar tradisional membutuhkan pembaharuan yang fundamental dan juga perubahan dalam cara berpikir (Stacey, Chick \& Kendal, 2004). Pembelajaran aljabar saat ini bertujuan menguasai konsep aljabar dan mengaplikasikan konsep aljabar di berbagai konteks kehidupan sehari-hari.

Guru matematika saat ini berpendapat bahwa pemahaman aritmatika merupakan tahap awal dalam memahami aljabar (Watson, 2009). Kecakapan matematika di bidang geometri dan pengukuran adalah dasar yang paling esensial dalam mempelajari aljabar. Di sekolah, aljabar diajarkan dengan pandangan aritmatika yaitu aritmatika adalah salah satu struktur aljabar yang bisa dikalkulasi. Ringkasnya, saat ini pembelajaran aljabar dipahami sebagai sebuah generalisasi dari aritmatika.

Ada beberapa persoalan yang muncul dari pandangan ini, Kieran (1992) menjelaskan bahwa terjadi kesulitan membuat transisi dari aritmatika ke aljabar. beberapa diantaranya adalah sebagai berikut: (1) fokus aljabar adalah hubungan antar variabel bukan sekedar perhitungan misalnya hubungan $a+b=c$, merepresentasikan dua bilangan yang tidak diketahui di dalam operasi penjumlahan, sedangkan $3+5=8$ merupakan sebuah hubungan yang dipahami sebagai cara lain untuk merepresentasikan 8 , sehingga $3+5$ dapat dihitung, sedangkan $a+b$ tidak; (2) Siswa harus dapat memahami invers dan operasi sehingga dalam mencari bilangan yang tidak diketahui misalnya, $7+b=4$ dapat dilakukan dengan pengetahuan mereka tentang operasi aljabar, tetapi $c+63=197$ akan lebih mudah dikerjakan dengan operasi pengurangan yaitu, operasi invers dari penjumlahan; (3) Beberapa situasi tidak bisa langsung dihitung untuk mendapatkan jawabannya, tapi harus diekspresikan terlebih dahulu ke dalam ekspresi aljabar; (4) huruf dan bilangan digunakan seacara bersama-sama sehingga bilangan dapat diartikan sebagai simbol pada sebuah struktur ekspresi aljabar, sebagai contoh: struktur $2(a+b)$ berbeda dengan struktur $2 a+2 b$ walaupun keduanya ekuivalen dalam hal perhitungan; (5) tanda sama dengan '=' memiliki makna yang lebih luas; pada aritmatika, tanda sama dengan berarti 'hitung' atau 'kalkulasi' sedangkan pada aljabar, tanda ' $=$ ' dapat berarti '.. sama dengan...' atau '....ekivalen dengan..' .

Namun, kesulitan yang djabarkan oleh Kieran (1992) dapat dijembatani dengan adanya pembelajaran yang memungkinkan transisi dari aritmatika ke aljabar karena lompatan pemikiran tidak dapat serta merta muncul pada siswa melalui pembelajaran tanpa adanya transisi. Beberapa pemahaman dari pengetahuan aritmatika harus ditransformasi sedemikian rupa sehingga dapat membantu siswa mengembangkan kemampuan berpikir aljabar. Kemampuan berpikir aritmatika tidak bisa langsung dimanfaatkan oleh siswa untuk modal mengembangkan kemampuan bepikir aljabar (Blair, 2003).

Pada studi ini, akan diselidiki bagaimana pembelajaran aljabar secara keseluruhan dilakukan oleh guru, kemudian akan dijelaskan bagaimana bentuk transisi kemampuan berpikir aritmatika ke kemampuan berpikir aljabar dengan menginvestigasi pengetahuan siswa melalui tes, pada akhirnya akan dideskripsikan faktor apa saja yang mendukung munculnya transisi dari kemampuan berpikir aritmatika ke kemampuan berpikir aljabar. Untuk menjawab beberapa masalah di atas, studi tentang pembelajaran matematika SMP ditinjau dari transisi kemampuan berpikir aritmatika ke kemampuan berpikir aljabar lantas dilaksanakan.

Studi ini bertujuan untuk mengetahui gambaran tentang transisi kemampuan berpikir aritmatika ke kemampuan berpikir aljabar. Salah satu alasan aljabar menjadi masalah bagi siswa di sekolah adalah karena sifat keabstrakannya. Ide-ide pada aljabar terhubung pada semua bidang kajian dalam matematika dan juga terdapat beberapa konteks di luar bidang matematika (Breteig dan Grevholm, 2006). Oleh 
karena itu, pembelajaran aljabar bagi siswa melalui beberapa contoh masalah yang berbeda sangat diperlukan untuk memperdalam pengetahuan mereka terhadap aljabar.

Blanton dan Kaput (2005) menemukan beberapa kategori berbeda pada penalaran aljabar, yaitu: generalized mathematics, functional relationship, properties of numbers and operations, dan algebraic treatment of number. Beberapa kategori ini mengindikasikan pengetahuan-pengetahuan yang harus dikuasai oleh siswa dalam mempelajari aljabar. Sebuah transisi pengetahuan diperlukan agar siswa tidak kesulitan memahami aljabar. Alasan mengapa diperlukan transisi ini adalah karena aritmatika dan aljabar memiliki kesamaan penggunaan simbol dan operasi namun merepresentasikan hal yang berbeda.

Sebagai contoh, pada aritmatika sekolah dasar, lebih ditekankan "calculating answer" yang berarti bahwa tanda sama dengan pada ekspresi " $5+3=8$ " merepresentasikan bilangan di sebelah kanan tanda 'sama dengan' adalah jawaban dari ekspresi sebelah kiri tanda 'sama dengan'. Pemaknaan tanda sama dengan tersebut akan menyulitkan siswa dalam memahami ekspresi " $2+5=a+8$ ", karena pada ekspresi tersebut tanda 'sama dengan' tidak lagi berarti 'jawaban' namun menyatakan hubungan dari ruas kiri dan kanan. Oleh karena itu, harus ada transisi dari aritmatika ke aljabar yang memungkinkan siswa dapat memaknai simbol 'sama dengan' sebagai sebuah relasi ekspresi.

Terdapat celah perbedaan antara kemampuan aritmatika dan kemampuan aljabar yang harus dijembatani dengan sebuah pembelajaran matematika dan desain instruksional di kelas yang dapat memotivasi munculnya sebuah transisi kemampuan. Hal ini selaras dengan tujuan penelitian ini yaitu untuk menyelidiki pembelajaran dilihat dari aspek tersebut. Jika memang pembelajaran dirasa sudah memunculkan ide-ide yang mendukung lompatan pengetahuan dan transisi kemampuan, maka perlu dideskripsikan bagaimana transisi tersebut terjadi dengan menjelaskan proses berpikir siswa dimulai dari menalar, menjelaskan, menyanggah, menggeneralisasi, dan menjustifikasi (Breteig \& Grevholm: 2009). Maka transisi kemampuan berpikir aritmatika ke kemampuan berpikir aljabar dapat dijelaskan dengan menginvestigasi kemunculan indikator-indikator transisi.

Beberapa penelitian menunjukkan bahwa siswa pada sekolah menengah menggunakan variabel tanpa pemahaman yang mendalam tentang fleksibilitas sistem simbol pada aljabar. Mereka mengembangkan pengetahuan mereka dalam aljabar sebagai manipulasi yang rutin, berdasarkan pengetahuan bahwa variabel mengikuti aturan-aturan yang sama seperti pada perhitungan bilangan. Yang membuat aljabar berbeda dengan aritmatika adalah bahwa aljabar mampu merepresentasikan lompatan pada pembelajaran. (Kieran, 1992; English \& Halford, 1995; Wagner \& Kieran, 1989; Bell, 1995).

Berdasarkan temuan dari studi Breteig dan Grevholm (2006) hanya sedikit dari siswa yang mereka investigasi dapat menalar sebuah masalah aljabar dengan justifikasi yang tepat, siswa yang lain hanya membuat beberapa alasan yang tidak ada kaitannya dengan aljabar. Penelitian ini berusaha mencari gambaran tentang bagaimana transisi kemampuan berpikir aritmatika ke kemampuan berpikir aljabar terjadi pada siswa SMP serta mencari faktor yang mempengaruhi transisi tersebut. Tulisan ini berusaha menjabarkan dan menganalisis hasil jawaban siswa terhadap masalah aljabar tertentu dan melihat apakah ada tahapan atau lompatan pengetahuan siswa tentang aritmatika yang digunakannya untuk menjelaskan sebuah struktur dalam aljabar. Masalah aljabar berupa tes yang akan didesain bukan merupakan tes untuk menguji pemahaman pada konsep aljabar tertentu, namun akan lebih menekankan pada penggunaan simbol dan operasi, manipulasi variabel, serta pemaknaan sebuah struktur dalam aljabar.

Dari deskripsi di atas, maka dapat disimpulkan beberapa hal yang perlu 


\section{JURNAL GANTANG. Maret 2018; III(1): 1 - 8 \\ p-ISSN. 2503-0671 \\ e-ISSN. 2548-5547}

diinvestigasi untuk melihat munculnya transisi kemampuan berpikir aritmatika ke kemampuan berpikir aljabar yaitu sebagai berikut.

1. Siswa dapat mengenali hubungan sebuah ekspresi matematika bukan pada perhitungan matematika.

2. Siswa dapat memaknai operasi dan invers.

3. Siswa dapat melakukan generalisasi dari hubungan matematika di suatu konteks tertentu.

4. Pada konsep aljabar, siswa dapat memaknai huruf dan bilangan yang digunakan bersamasama sebagai sebuah struktur ekspresi aljabar.

5. Siswa dapat membedakan tanda "sama dengan" bukan berarti "menghitung hasil dari" namun sebagai hubungan persamaan antara ekspresi matematika di ruas kanan dan ruas kiri.

6. Siswa dapat memahami aritmatika sebagai hubungan yang general dalam kuantitas tertentu.

7. Siswa dapat memaknai operasi pembagian sebagai dasar dalam membangun ekspresi rasional.

8. Siswa dapat mengerti bahwa nilai dari suatu bilangan tidak terlalu penting, tetapi yang terpenting adalah hubungannya dengan bilangan lain sebagai sebuah ekspresi atau struktur matematika.

\section{Metode Penelitian}

Pendekatan penelitian yang digunakan adalah kualitatif dengan jenis penelitian studi kasus. Studi kasus dipilih karena peneliti berupaya untuk menelaah, membuat interpretasi dan mendapat pemahaman yang mendalam dan menyeluruh tentang transisi berpikir aritmatika ke berpikir aljabar.

Metode pengumpulan data yaitu tes dan wawancara. Soal tes yang digunakan sesuai dengan indikator transisi kemampuan berpikir aritmatika ke kemampuan berpikir aljabar. Wawancara digunakan untuk menggali lebih dalam tentang berpikir siswa terutama mengenai kemampuan berpikir aritmatika ke kemampuan berpikir aljabar.

\section{Hasil dan Pembahasan}

Pengambilan data dilakukan di SMP Negeri 1 Palembang. Instrumen yang digunakan telah divalidasi oleh pakar berupa soal-soal tentang aritmatika dan aljabar dasar untuk siswa SMP. Instrumen soal aritmatika meliputi soalsoal untuk operasi kali, tambah, bagi, dan kurang serta pemangkatan dan pecahan. Sedangkan untuk soal aljabar, pokok bahasan yang dipilih adalah pada tahap awal pengenalan aljabar tentang variabel, koefisien, dan konstanta serta soal cerita sederhana tentang permasalahan yang terkait dengan aritmatika dan aljabar. Sebanyak 30 siswa dilibatkan sebagai subjek penelitian ini. Siswa yang dipilih adalah siswa yang sudah mendapatkan pelajaran tentang pokok bahasan aljabar.

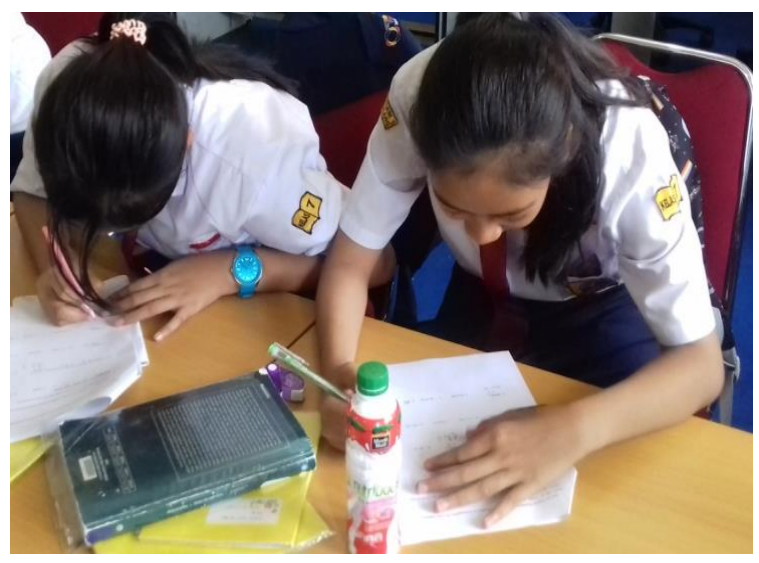

Gambar 1. Siswa mengerjakan instrumen soal

Kemampuan siswa beragam mulai dari level rendah, sedang, hingga tinggi. Hasil pengerjaan siswa dikumpulkan untuk dianalisis kemudian dilakukan wawancara untuk mengklarifikasi jawaban mereka terhadap soal yang diberikan. Adanya transisi dari kemampuan berpikir aritmatika ke kemampuan berpikir aljabar dilihat dari beberapa indikator berikut: (1) membedakan variabel, koefisien, dan konstanta, (2) mengenali tanda operasi dan tanda bilangan, (3) menggunakan sifat dalam operasi aljabar, (4) menggunakan konsep aritmatika ke dalam ekspresi aljabar, (5) melakukan 
generalisasi dalam bentuk aljabar.

Instrumen soal memuat 15 pertanyaan diawali dengan 5 soal aritmatika untuk melihat kemampuan artimatika siswa 10 soal aljabar untuk mengukur kemampuan aljabar siswa.

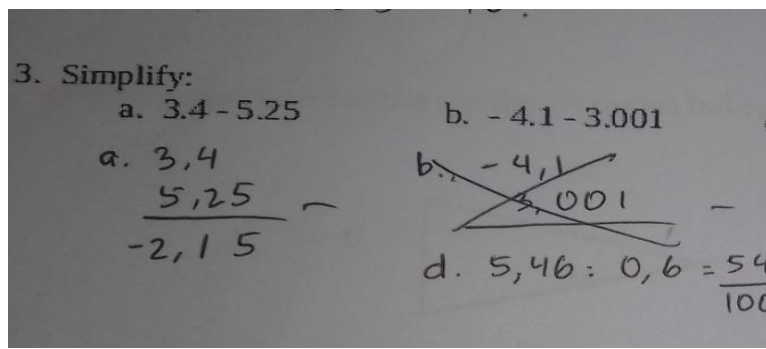

Gambar 2. Jawaban siswa untuk soal aritmatika

Pada gambar jawaban siswa di atas, siswa diminta untuk dapat mengerjakan operasi aritmatika dasar seperti operasi pengurangan bilangan desimal. Soal ini bertujuan untuk melihat gambaran tentang kemampuan dasar aritmatika siswa dalam melakukan operasi bilangan desimal. Dari jawaban tersebut, siswa menjawab pertanyaan tentang pengurangan bilangan desimal. Dari jawaban tersebut, siswa terlihat belum memahami aturan dalam mengurangkan bilangan desimal dari bilangan desimal yang lain. Siswa melakukan operasi pengurangan seperti melakukan operasi bilangan bulat biasanya dengan cara melakukan pengurangan ke bawah. Siswa memaknai bilangan desimal 3, 4 sebagai 3,40 sama halnya dengan 340 dan memaknai 5,25 sama halnya dengan 525. Lalu, siswa mengurangkan 2 bilangan di belakang koma sebagai 40 dikurang 25 sehingga diperoleh hasil 15 sebagai bilangan di belakang koma. Sedangkan untuk bilangan di depan koma yaitu 3 dan 5, siswa melakukan pengurangan secara langsung sehingga didapat nilai -2 . Oleh sebab itu, hasil pengurangan bilangan desimal antara 3,4 dan 5, 25 yaitu -2 , 15. Dari proses pemikiran seperti ini terlihat jelas sekali siswa tidak memahami makna nilai tempat dari bilangan desimal. Kemampuan memaknai nilai tempat dari suatu bilangan merupakan kemampuan dasar dari siswa untuk bisa melakukan operasi dalam bilangan.

Untuk soal yang sama, siswa lain kurang teliti dalam menuliskan operasi pada bilangan bulat negatif, untuk mempermudah pengerjaan siswa mengganti tanda operasi menjadi positif, tapi hal ini yang menyebabkan kekeliruan sehingga siswa lupa menambahkan tanda negatif pada hasil operasi.

Dari kedua jawaban ini terhadap operasi pengurangan bilangan desimal terlihat bahwa masih ada siswa yang belum bisa mencapai indikator yang kedua yaitu dapat membedakan tanda bilangan dan tanda operasi, terutama untuk tanda negatif dan operasi pengurangan. Hal ini adalah sangat fundamental untuk dapat dikuasai oleh siswa karena bekal dalam mempelajari aljabar.

Untuk indikator menggunakan sifat-sifat operasi aljabar, sebagian siswa sudah dapat menggunakannya dengan baik, hanya saja masih ada siswa yang belum teliti dalam melakukan perhitungan sehingga masih banyak yang keliru dalam memperoleh hasil perhitungan.

Untuk soal nomor 6 dan 7 di bawah ini, siswa menggunakan sifat distributif pada persamaan dan dapat menyederhanakan suatu ekspresi aljabar menjadi bentuk yang lebih sederhana. Contoh jawaban lain adalah siswa dapat menggeneralisasi suatu bentuk aljabar.

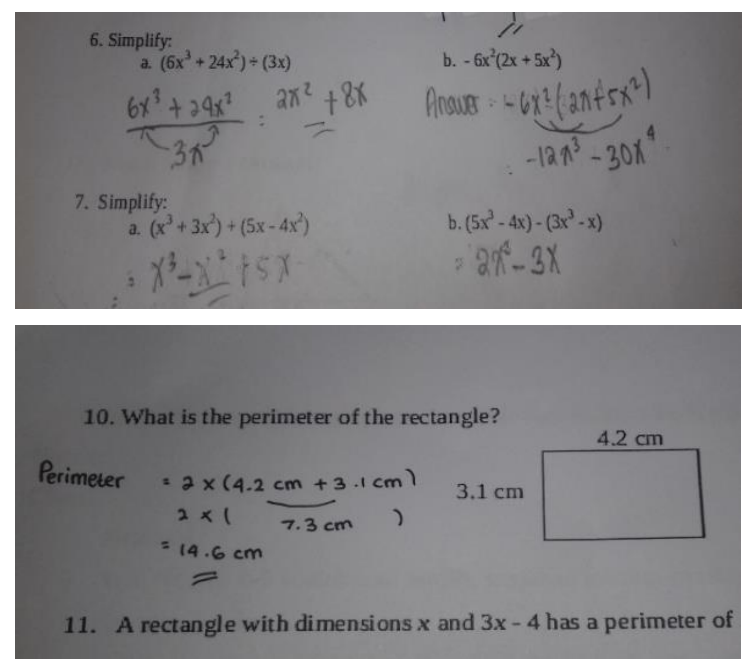

Gambar 3. Siswa melakukan prosedur operasi pada aljabar 


\section{JURNAL GANTANG. Maret 2018; III(1): 1 - 8 \\ p-ISSN. 2503-0671 \\ e-ISSN. 2548-5547}

Soal di atas memperlihatkan kemampuan siswa dalam menggunakan operasi aljabar pada soal cerita. Siswa dapat memberikan gambaran tentang penggunaan aljabar pada situasi tertentu. Siswa juga dapat memilih operasi mana yang harus dilakukan terlebih dahulu agar perhitungannya tepat. Dari beberapa contoh jawaban siswa di atas maka dapat disimpulkan siswa telah dapat mencapai indikator transisi kemampuan berpikir aritmatika ke kemampuan berpikir aljabar terutama pada indikator menggunakan sifat-sifat operasi aljabar. Namun siswa masih kesulitan dalam membedakan tanda operasi dan tanda bilangan, terutama dalam mengoperasikan bilangan negatif. Siswa dalam hal ini, tidak mengalami masalah dalam membedakan koefisien, variabel, dan konstanta.

Berdasarkan hasil wawancara dengan siswa, sebagian besar siswa dapat menyebutkan definisi koefisien, variabel dan konstanta dengan benar. Koefisien adalah bilangan yang memuat variabel dari suatu suku di aljabar, variabel adalah lambang pengganti suatu bilangan yang belum diketahui nilainya dan dilambangkan berupa huruf, sedangkan konstanta adalah suku di aljabar yang tidak memuat variabel berupa bilangan.

Secara keseluruhan, lebih dari $60 \%$ siswa mendapatkan nilai tes lebih dari 70 . Berikut tabel nilai hasil tes dari 15 soal yang diberikan untuk 30 orang siswa SMP.

Tabel 1. Hasil tes siswa

\begin{tabular}{|c|c|}
\hline Nilai & Frekuensi \\
\hline $86-100$ & 6 \\
\hline $70-85$ & 13 \\
\hline $56-69$ & 7 \\
\hline $40-55$ & 4 \\
\hline $0-39$ & 0 \\
\hline
\end{tabular}

Dari tabel di atas, kita dapat melihat bahwa masih ada siswa yang mendapatkan nilai di bawah 70 yaitu 11 orang. Hal ini menunjukkan bahwa terdapat beberapa kesulitan yang dialami siswa dalam mempelajari aritmatika dan aljabar. Oleh sebab itu, diperlukan perhatian yang khusus oleh guru untuk memahami kesulitan siswa tersebut.

Indikator kemampuan yang paling sulit bagi sebagian besar siswa yaitu mengenali tanda operasi dan tanda bilangan, terutama operasi pengurangan dan tanda bilangan negatif. Dari analisis hasil tes siswa, sebagian besar siswa mengalami kesulitan dan keliru dalam melakukan perhitungan operasi pengurangan untuk bilangan negatif. Hal ini disebabkan karena siswa tidak bisa membedakan dan memaknai tanda bilangan dan operasi bilangan, sehingga ketika melakukan perhitungan siswa melakukan operasi bilangan yang keliru. Tanda bilangan $(+a$ atau $-a)$ berfungsi untuk menentukan jenis bilangan tersebut yaitu bilangan positif atau bilangan negatif, sedangkan operasi bilangan $(a+b$ atau $a-b)$ merupakan operasi yang dilakukan terhadap dua bilangan (Reys, 1991). Berdasarkan hasil wawancara dengan siswa, terlihat juga bahwa siswa melakukan kesalahan dalam pengucapan tanda baca untuk tanda bilangan berupa dikurang menjadi minus yang merupakan cara baca untuk tanda suatu bilangan.

Lain halnya dengan indikator menggunakan sifat dalam operasi aljabar. Sebagian besar siswa dapat menggunakan sifat dalam operasi aljabar, misalnya menggunakan sifat distributif dalam menyelesaikan perhitungan ataupun dalam soal cerita.

\section{Penutup}

$\begin{array}{rlcr}\text { Berdasarkan } & \text { hasil tes diperoleh } \\ \text { informasi bahwa } & 60 \% & \text { siswa mampu }\end{array}$ mengerjakan soal dengan cukup baik, walaupun begitu masih ada siswa yang mengalami kesulitan dalam menjawab soal tes. Dari analisis hasil tes, indikator yang paling sulit bagi siswa adalah mengenali tanda bilangan dan operasi bilangan. Berdasarkan pengerjaan siswa, sangat terlihat sekali beberapa siswa sebagian besar siswa mengalami miskonsepsi dari makna tanda bilangan dan operasi bilangan. Sedangkan indikator yang paling dipahami siswa yaitu menggunakan sifat dalam operasi aljabar. 
Pembelajaran dikelas hendaknya dapat mengakomodir kemampuan berpikir aljabar siswa dengan baik karena kemampuan aljabar siswa sangat mereka perlukan untuk memahami pembelajaran topik matematika yang lain dan juga pokok bahasan pada mata pelajaran lain. Siswa harus diberikan situasi dalam soal sehingga mereka dapat mengembangkan kemampuan dalam memberi makna pada ekspresi aljabar dan membuat generalisasi bentuk aljabar.

\section{Ucapan Terimakasih}

Peneliti mengucapkan terima kasih kepada Universitas Sriwijaya karena penelitian ini adalah pemenang Hibah Penelitian Sains Teknologi dan Seni (SATEKS) yang didanai oleh Universitas Sriwijaya tahun angaran 2017.

\section{Referensi}

Abrahamson, D., \& Cendak, R. M. (2006). The odds of understanding the law of large numbers: A design for grounding intuitive probability in combinatorial analysis. In Proceedings of the 30th Conference of the International Group for the Psychology of Mathematics Education (Vol. 2, pp. 1-8).

Bell, A. (1995). Purpose in school algebra. The Journal of Mathematical Behaviour, 14(1), 41-73.

Blanton, M. L., \& Kaput, J. J. (2005). Characterizing a classroom practice that promotes algebraic reasoning. Journal for Research in Mathematics Education, 36(5), 412-446.

Blair, L. (2003). It's Elementary: Introducing Algebraic Thinking Before High School. SEDL Letter, 15(1), 16-20.

Breteig, Grevholm. (2006). In Novotná, J., Moraová, H., Krátká, M. \& Stehlíková, N. (Eds.). Proceedings 30th Conference of the International Group for the Psychology of Mathematics Education, Vol. 2, pp. 225232. Prague: PME. 2 - 225

Chick, H., Stacey, K., Vincent, J., \& Vincent, J. (2001). The future of the teaching and learning of algebra. In Proceedings of the 12th ICMI Study Conference. University of Melbourne.

English, L. D., \& Halford, G. S. (1995). Mathematics education. Models and processes. Mahwah, NJ: Lawrence Erlbaum.

Falkner, K., Levi, L., \& Carpenter, T. (1999). Children's Understanding of Equality: A Foundation for Algebra. Teaching Children Mathematics, 6(4), 232-236.

Herman, T. (1996). Pupils' strategies in mental computation. Deakin University.

Kieran, C. (1992). The learning and teaching of school algebra. In D. A. Grouws (Ed.), Handbook of research on mathematics teaching and learning. New York: Macmillan.

Kieran, C. 2004. Algebraic Thinking in the Early Grades: What Is It? The Mathematics Educator, 8(1): 139-151.

Kouba, V. L., Carpenter, T. M., \& Swafford, J. O. (1989). Number and operation. In M. M. Lindquist (Ed.), Result from the fouth mathematics assessment of educational progress (pp. 64-93). Virginia: NCTM McIntosh, A.

LeFervre, J.-A., Smith-Chant, B. L., Hiscock, K., Daley, K. E., \& Morris, J. (2003). Young adults' strategic choice in simple arithmetic: Implications for the development of mathematical representations. In A. J. Baroody \& A. Dowker (Eds.), The development of arithmetic concepts and skills: constructing adaptive expertise (pp. 203228). Mahwah, NJ, US: Lawrence Erlbaum Associates Publishers,.

Manly, Myrna \& Ginsburg, Lynda. (2010). Algebra thinking in adult education. Washington DC: National Institute for Literacy

Moleong, L. J. (2006). Metode Penelitian Kualitatif. Bandung: Remaja Rosda Karya.

National Council of Teachers of Mathematics. (2000). Principles and standards for 
JURNAL GANTANG. Maret 2018; III(1): 1 - 8

p-ISSN. 2503-0671

e-ISSN. 2548-5547

school mathematics. Reston, VA: NCTM.

Nunes, Terezinha, Bryant, Peter, \& Watson, Anne. (2009). Key understandings in mathematics learning: Overview. London: Nuffield Foundation.

Reys, R. (1991). Ideas for developing mental computation. Brisbane: Queensland University of Technology.

Reys, R., \& Reys, B. (1995). Mental computation and mental estimation. Teaching Children Mathematics, 1(8).

Sowder, J. (1991). Mental computation and number sense. Arithmetics Teacher, 37(7), $18-20$.

Wagner, S., \& Kieran, C. (1989). Research issues in the learning and teaching of algebra. Reston, VA: NCTM.

Watson, Anne. (2009). Key understandings in mathematics learning: Algebraic reasoning. London: Nuffield Foundation. pendidikan karakter dalam pembelajaran sastra remaja. Cakrawala Pendidikan, XXXII(3), 382-393. doi: $10.21831 /$ cp.v3i3.1626 